\title{
The Effects of Development Strategy and Regional Competitiveness on Investment of Marine-Tourism Industry in East Belitung Regency
}

\author{
Reniati \\ Khairiyansyah
}

Bangka Belitung University, E-mail: r3ni4ti@yahoo.com; E-mail : khairiyansyah.supendi@gmail.com

\author{
Doi:10.5901/mjss.2015.v6n5s5p189
}

\begin{abstract}
Increased investment in the region is one of the important instruments in achieving sustainable regional economic development to the welfare of society. The investment value of East Belitung province until 2013 in the fourth quarter increased in the amount of $18 \%$ or Rp. 462,807,663,854 which was also in line with the growth of projects and labors unless the marine and tourism sector. Based on preliminary observation, this diversity is probably caused by low development strategy and competitiveness whereas Beltim economic development vision is: "Creating East Belitung as the Regional Industry with Agriculture, Marine and Fisheries, and Integrated Economic Democracy-Based on Bangka Belitung Archipelago". The method used was descriptive-verificative with verification analysis tool by Structural Equation Modeling (SEM) through variants structure-based approach or Partial Least Square Path Modeling. The number of respondents was 48 people consisting of four elements, namely local government offices, business people, BUMD directors, and academic personnel. The results show that there is a positive and significant effect of the development strategy and contribution of regional competitiveness for MarineTourism industry investment. The role of development strategy and regional competitiveness is significantly to improve the industry investment of Marine-Tourism. Regional competitiveness variable causes greater effect than development strategy. Therefore, East Belitung regency should improve its competitiveness as soon as possible either institutional, political and sociocultural security, regional economics, labor and physical infrastructure.
\end{abstract}

Keywords: Development srategy, regional competitiveness, industry investment marine-tourism.

\section{Introduction}

\subsection{The Study Background}

Economic development in various regions in Indonesia and the world is now faced with a condition called economic globalization. Globalization is an era or period in which the flow of goods and services (including information) freely in and out of the territorial boundaries of a nation or by using the term Ohmae (1995) era is referred to the borderless world. In that era, freedom " 41 " such as investment, industrialization, information, and individual consumers will emerge.

Beltim economic development vision in RPJM (2010) is: "Creating East Belitung as the Regional Industry with Agriculture, Marine and Fisheries (Agro Fisheries Industry), and Integrated Economic Democracy-Based on Bangka Belitung Archipelago". This vision implies that at the end of the next planning period (2030), the economy of East Belitung province will be supported by two major economic powers, namely large-scale industry which processes agricultural products, fisheries and marine which are in line with the integrated economic development. East Belitung regency has excellent tourism can be created through long-term development, namely Marine-tourism such as shore excursions, island tours, marine tourism, coastal travel nuanced, small islands, and marine (coral reefs, diving, surfing, and snorkeling), beach hotels, beach restaurant, beach sports, beach art, and others; and Marine-industry such as sea fishing, fish breeding, cultivation of seaweed, sea fishing industry, new shipbuilding, ship repair industry, marine energy industry, and other marine-based industries. The level of city competitiveness becomes a measure that determines the potential area for investment.

Based on the real data, investment value of East Belitung province until 2013 at the fourth quarter increases in the amount of $18 \%$ or Rp. 462807663854 . Total projects also rise, so does the number of the workforce. But for investment in marine and tourism is still minimal due to the low development strategies and competitiveness through preliminary observations. 


\subsection{Research Problems}

Based on the research background above, Several problems can be formulated as the following:

1. What is the influence of investment strategy to marine-tourism industry in East Belitung province?

2. What is the contribution of regional competitiveness to the investment of marine-tourism industry in East Belitung province?

3. What is the role of development strategies and regional competitiveness to the investment of marine-tourism industry in East Belitung province?

\subsection{Research Purposes}

1. To obtain a study on the effects of development to the investment of marine-tourism industry in East Belitung regency.

2. To obtain a study on the contribution of regional competitiveness to the investment of marine-tourism industry in East Belitung regency.

3. To obtain a study on the role of development strategy and regional competitiveness to the investment of marine-tourism industry in East Belitung regency.

\section{Literature Review}

\subsection{Regional Development Strategy}

The classical interpretation defines strategy as a rationally intended package of measures in order to achieve long term goals. Chandler defines strategy as the determination of the basic long term goals and objectives of an enterprise, and adoption of a course of action and the allocation of resources necessary for carrying out these goals (Tobias, 2008:15). The proncipal subactivities of strategy formulation as a logical activity include identifying opportunities and threats in the company's environment and attaching some estimate risk to descernible alternatives. Before a choice can be made, the company's strengts and weaknesses should be appraised together with the recources at hand and available (Rasche, 2008:20).

Mintzberg, etc. (2008) determines strategy as three items: (1) Strategy as plan: intended strategies that can be general or spesific, (2) Strategy as ploy: maneuver intended to surprise an opponent or competitor, (3) Strategy as pattern: it emphasizes that strategy is the consistency in behavior over time. Wether or not intended.

Strategies are a number of decisions and actions aimed to achieve the goal and adjust the organization's resources with the opportunities and challenges facing the industrial environment (Coulter, 2002: 7). Based on the identification of levels and elements for the purpose of ranking the regional competitiveness of regency or city to the investments, from the understanding of literature studies, opinions of business people, the input of experts and the rating done by KPPOD (2005) variables that affect competitiveness of regional investment are classified as follows: (1) Institutions, (2) Political and Socio-Cultural Security, (3) Regional Economics, (4) Labour, and (5) Physical Infrastructure. Institutions have indicators such as legal certainty, personnel and services, regional policy, and local leadership. According to Arsyad (2005:122-126) development strategies of regional economics can be classified into four types:

\section{Physical or Locality Development Strategy}

Local governments will give positive influence for the development of local business through the development program in improving the physical condition / locality area devoted to the interests of the construction industry and commerce. In particular, the goals of physical development strategies / locality are to create a regional identity, to improve amenity base or quality of community's life, and to improve the attractiveness of the civic center in order to improve local business.

\section{Development Strategy for Local Business}

Business development is an important component in local economic development plan since the attraction, creation, or durability of business activities is a great way to create a healthy local economy. Several tools are used to develop business world such as: (1) The creation of a good business climate for business, (2) Preparation of an integrated information center, (3) Establishment of consultation centers and small business development, (4) Establishment of a 
joint marketing system to avoid uneconomic scale in production, to improve the competitiveness of the imported products, and to increase cooperation among fellow business people, (5) Preparation of research and development institutions.

\section{Development Strategy for Human Resources}

Human resources are the most important aspects in the process of economic development. Therefore, improving the quality and skills of human resources is a necessity and it is essential to improve the competitiveness of a region.

\section{Development Strategy for the Community's Economic}

The community's economic development is an activity to develop a certain group of people in an area. In popular language, it is known as community empowerment. Such activity thrives recently in Indonesia because of the unable economic policy in providing benefits to certain groups.

\subsection{Competitiveness}

The strategy may have been developed explicitly through a planning process or it may have evolved implicitly through the activities of the various functional departments of the firm. Left to its own devices, each functional department will inevitably pursue approach dictated by its professional orientation and the incentives of those in charge. However, the sum of these departemental approaches rarely equals the best strategy (Porter, 1998) and |(Thompson, et.all, 2010). This fact is similar to local government in term of how to upgrade its competitiveness.

In general, economic development in East Belitung regency has been developed based on three main strategies, namely durability, attractiveness and competitiveness. Basically those strengths are linked one another. In the context of local economic development of East Belitung, the priority to emphasize the strengths is adapted to the stage of economic development itself.

According to Sri Rayahu and Yuka Asamara (2013), competitiveness is an effort must be done by the business/economy people to exist in carrying out their activities. Ayu Kartika Megasari (2013) defines competitiveness as the ability to maintain market share. Increased competitiveness in the tourism sector utilizes the tourist visiting to Belitung island. Development of tourist attraction should be improved in order to divert tourists to visit the tourism spots in Belitung regency. Developed tourism must have a uniqueness so that tourists have a reason to come to East Belitung.

\subsection{Investment}

Local inward investment consists of actions that help retain existing businesses in the local economic development area. This encompasses a wide range of potential actions that might include the following (UN Habitat, 2005): (1) Creating a business-friendly through training programs and business support programs, (2) Providing improved access to flexible credits options (3) Bureaucracy reduction programs, (4)Encouraging local economic activity (5) Hard and soft infrastructure investments to support the local economy.

The concept of regional market in general is able to meet and satisfy the desires and expectations of its customers such as traders, tourists, and investors. According to Hermawan Kertajaya and Yuswohadi (2005), strategic steps to attract investors are being a good host for local customers, treating your guest properly, and building a home sweet home for investors and tourists. Small and large scale enterprises, whether that is the profit or nonprofit motives will have a major concern in the field of finance.. One of such financial decisions is an investment. Indra Setiawan and Deddy $\mathrm{S}$ Bratakusumah (2010, p.178) states that investments are closely linked and have a negative relationship with the determination of the interest rate of SBI. In addition, Engla Desnim Silvia, et al $(2013, p .236)$ shows that investment is also influenced positively and significantly to the economic growth.

Investment appraisal method by Dermawan Syahrial (2007) refers to the payback period method, bank discount return method, an average rate method of return, net present value method, the internal rate of return method, the modified internal rate of return method, the index method earnings capacity, and method of clean present value. 


\section{Research Methods}

\subsection{The method used}

This research majors in economics management that focuses on strategic management as its Grand Theory. The Middle Theory conveys the financial management and the Applied Theory concerns in variables of regional development strategies, regional competitiveness, and investment of marine-tourism industry. The research is descriptive and verificative through field data collection, that is descriptive and explanatory survey. (Hair, et.all, 2010)

\subsection{Sampling Method}

Technique of determining the data used in this research is purposive sampling method by selecting respondents deliberately to represent the population. The number of respondents was 48 people consisting of four elements namely local government officials, business people, BUMD directors, and academic personnel. Based on these samples, the basis used to test hypotheses on the PLS is resampling with bootstrapping developed by Geisser \& Stone (1974). The sample size in the PLS can be estimated as follows: (1) Ten times of the amount of formative indicators (ignoring reflexive indicator). (2) Ten times of the number of structural lines (structural paths) on the inner models. (3) Small sample size from 30 to 50 or large sample greater than 200

\subsection{Analysis Plan and Hypothesis Testing}

Verification analysis in this study uses Structural Equation Modeling (SEM) with variant structure-based approach or Partial Least Square Path Modeling. This technique is chosen for the measurement of latent variables involves reflective and formative indicators that can not be solved by SEM model with covariance structure-based. In addition, the complexity of the model involving moderator variables will be efficiently resolved by using Partial Least Square (PLS) compared with SEM LISREL (Hair, et al, 2010: 757).

\section{Data Analysis and Result}

Prior to testing the hypothesis, the first step is estimating the parameter model presented in the following diagram:

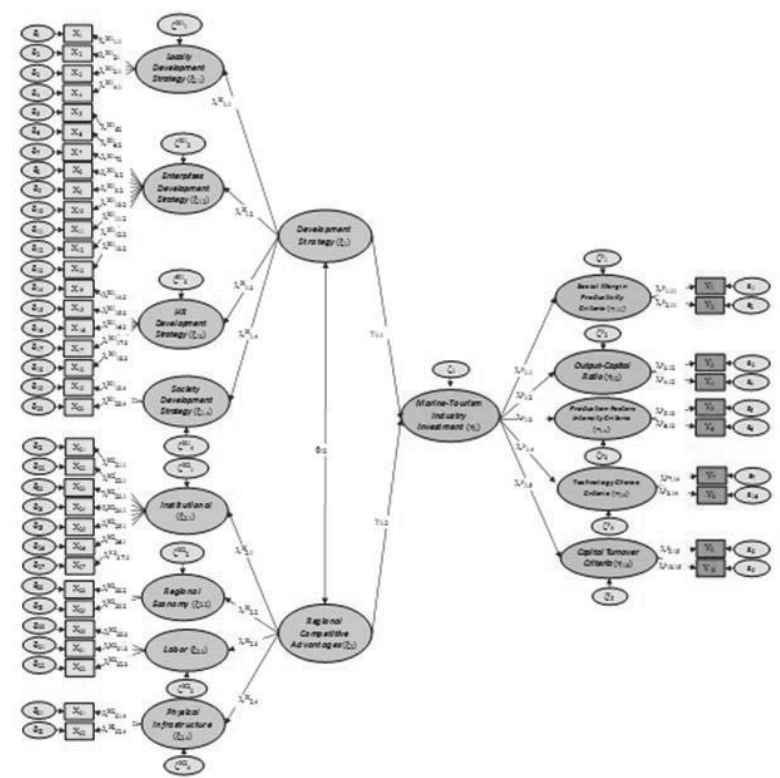

Figure 1: Flow Chart of Research 
The diagram above shows the estimation of each parameter model that includes parameters of validity and effect. In general, the model can be inferred either since the loading factor or validity coefficient greater than 0:50 unless there are some items such as X26 and X27 that have a validity coefficient less than 0:50, but still greater than 0:30 so that they can be considered valid in measuring institutional dimensions.

The model above shows the analysis of the validity and reliability of the second order measurement for development strategy variables. Second order measurement is a model of dimensional measurement on items. All items overall have a validity coefficient greater than $0: 50$ and construct reliabilty coefficient greater than 0.70 . Therefore, the second order measurement model for development strategy variables can be claimed valid and reliable.

First order measurement is measuring variables on its dimensions. All dimensions have a validity coefficient greater than 0:50 and reliability coefficient greater than 0.700 unless there are some items such as X26 and X27 that have a validity coefficient less than 0:50, but still greater than 0:30. So, the first order measurement for development strategy variables can be considered valid and reliable. The most dominant dimension in measuring development strategy variables is dimension of business development strategy. This result means that the development strategy is closely related to how local governments do business development strategy.

First order measurement is measuring variables on its dimensions. All dimensions have a validity coefficient greater than 0:50 and reliability coefficient greater than 0.700 . So the first order for the measurement of regional competitiveness variables can be claimed valid and reliable. The most dominant dimension in measuring the regional competitiveness variables is the institutional dimension. This result means that regional competitiveness is closely related to how local governments have high institutional competitiveness.

Overall all items have a validity coefficient greater than 0:50 and construct reliability coefficient greater than 0.70 so that the second order measurement model for investment variables of marine-tourism industry can be stated valid and reliable. All dimensions have a validity coefficient greater than 0:50 and reliability coefficient greater than 0.700 . So the first order measurement for investment variables of marine tourism industry can be stated valid and reliable. The most dominant dimension in measuring the investment variables of marine-tourism industry is the dimension of capital output ratio. This result means that the investment of marine-tourism industry is closely related to how local governments achieve good capital output ratio.

\section{Hypothesis Testing}

Furthermore, after all indicators and dimensions have been concluded valid and reliable, further analysis of structural models is done by test the significance of the variable effects according to the research hypothesis.

\subsection{Hypothesis 1, Development Strategy affects investment of Marine-Tourism Industry.}

$\mathrm{H}_{0}: \gamma_{11}=0$ Development Strategy does not influence the investment of Marine-Tourism Industry

$\mathrm{H}_{1}: \gamma_{11} \neq 0$ Development Strategy influences the investment of Marine-Tourism Industry

The calculation result provides a large influence from the development strategy to the investment of MarineTourism Industry about 0.267 . It means that any changes of one standard deviation of the development strategy will be able to increase investment of Marine-Tourism Industry in the amount of 0.267 or about $0.2672 \times 100 \%=7.13 \%$.

The calculation results yield $t$ value of 1.741 and $p$-value of 0.089 . By the significance level of $5 \%$ for positive test can be concluded that zero hypothesis is rejected, which means there is a significant influence on the development strategy of the investment of Marine-Tourism Industry with standard deviation of 0.267 or about $0.2672 \times 100 \%=7.13 \%$. F2 value in the amount of 0.074 is closed to the value of 0.02 indicates a weak influence from development strategy to the investment of Marine-Tourism Industry.

\subsection{Hypothesis 2, Regional Competitiveness affects the investment of Marine-Tourism Industri .}

$H_{0}: \gamma_{12}=0$ Regional competitiveness does not influence the investment of Marine-Tourism Industry

$\mathrm{H}_{1}: \gamma_{12} \neq 0$ Regional competitiveness influences the investment of Marine-Tourism Industry

The calculation result provides a large influence from the regional competitiveness to the investment of MarineTourism Industry about 0.470 . It means that any changes of one standard deviation of the regional competitiveness will be able to increase the investment of Marine-Tourism Industry in the amount of 0.470 or about $0.4702 \times 100 \%=22.09 \%$.

The calculation results yield $t$ value of 3.741 and p.value of 0.004 . By the significance level of $5 \%$ for positive test 
can be concluded that zero hypothesis is rejected, which means there is a significant influence on the regional competitiveness of the investment of Marine-Tourism Industry with standard deviation of 0.470 or about $0.4702 \times 100 \%=$ $22.09 \%$. F2 value in the amount of 0.230 is closed to the value of 0.15 indicates a weak influence from regional competitiveness to the investment of Marine-Tourism Industry.

\subsection{Hypothesis 3, Development strategy and Regional competitiveness affects the investment of Marine-Tourism} Industry.

$H_{0}: \gamma_{11}=\gamma_{12}=0$ Development Strategy dan regional competitiveness does not influence the investment of MarineTourism Industry

$\mathrm{H}_{1}$ : Minimal $\gamma_{1 i} \neq 0$ Development Strategy dan regional competitiveness influences the investment of MarineTourism Industry

The result of the calculation gives a large influence simultaneously from the development strategy and regional competitiveness to the investment of Marine Tourism Industry in the amout of 0.458 or about $45.8 \%$. It means that $45.8 \%$ of the changes in the investment of Marine Tourism Industry are affected by development strategy and regional competitiveness. Regional competitiveness variable provides the influence greater than the development strategy variable as presented in the following bar chart. The calculation result provides p.value of 0.000 , so it can be concluded that rejecting the zero hypothesis and accepting the hypothesis 1 which means the development strategy and the regional competitiveness affects the investment of Marine-Tourism Industry.

\section{Conclusion and Managerial Implications}

\subsection{Conclusion}

The conclusions of this research are:

1. There is a positive and significant influence from the development strategy to the investment of MarineTourism industry.

2. There is a positive and significant influence from the regional competitiveness to the investment of MarineTourism industry.

3. Development strategy and regional competitiveness affects the investment of of Marine-Tourism industry, regional competitiveness variable gives influence greater than development strategy variable.

\subsection{Managerial Implication}

1. Local government of East Belitung must improve its competitiveness by: (1) Institutions, (2) Political and SocioCultural Security, (3) Regional Economics, (4) Labour and (5) Physical Infrastructure. Institutions have indicators such as legal certainty, personnel and services, regional policy, and local leadership. Political and Socio-Cultural security has indicators namely security, politics, and culture. Regional economics has economic potential and economic structure indicator. Dimension of Labor has indicators such as labor availability, labor quality and cost of labor. Dimension of physical infrastructure consists of indicators namely the availability of physical infrastructure and the quality of physical infrastructure.

2. Local development strategy must also be improved by strengthening the business development strategy, human resources development strategy, and community development strategy, while Physical/Locality development strategy has been ideal.

\section{References}

Arsyad, Lincolin. (2005). Pengantar Perencanaan Pembangunan Ekonomi Daerah. Yogyakarta : BPFE-Yogyakarta.

Arsyad, Lincolin. (2010). Ekonomi Pembangunan (edisi 5). Yogyakarta : UPP STIM YKPN.

BKPMT (2015). Investment Report, Belitung Timur Region.

Bank Indonesia (2015). Kajian Ekonomi dan Keuangan Regional Provinsi Kepulauan Bangka Belitung Triwulan IV-2014. Kantor Perwakilan Bank Indonesia Provinsi Kepulauan Bangka Belitung.

Asmara, Yuka dan Rahayu, Sri, (2013), Meningkatkan Daya Saing Industri Kecil Menengah Melalui Inovasi dan Pemanfaatan Jaringan Sosial : Pembelajaran dari Klaster Industri Software di India. Pappiptek LIPI. 
Coulter, Mary. (2002). Strategic Management in Action,2nd ed. Prentice Hall New Jersey.

Cvijanovic et all. (2012). Macroeconomic Factors of Competitiveness of Serbian Economy ICT Sector. Drago Cvijonavic Management Association.p.714.

Djohanputro, Bramantyo, (2008) Manajemen Keuangan Korporat, PPM-Jakarta

Geisser, Stone (1974). Cross Validatory Choice and Assesment of Statistical Predictions. Journal of The Royal Statistical-Society Series B. 36(2). $111-147$

Hair, J.F. JR., Anderson, R.E, Tatham, R.L. \& Black, W.C. (2010). Multivariate Data Analysis. Six Edition. New Jersey : Pearson Educational, Inc

Kartajaya, Hermawan dan Yuswohadi (2005), Attracting Tourists, Trader, Investor - Strategi Memasarkan Daerah di Era Otonomi Daerah. PT. Gramedia Pustaka Utama-Jakarta.

Komite Pemantauan Pelaksanaan Otonomi Daerah (2005). Daya Saing Investasi Kabupaten/Kota Di Indonesia 2005 Persepsi Dunia Usaha. Peringkat 169 Kabupaten dan 59 Kota di Indonesia Metodologi dan Temuan Utama. KPPOD-USAID-Asia Foundation.

Megasari, Kartika Ayu. (2013). Identifikasi Kesiapan Daya Saing Industri Kecil Menengah Alas Kaki di Kota Mojokerto menghadapi Pasar Bebas ASEAN. Artikel IImiah Penelitian Mahasiswa 2013.

Mintzberg, Henry, Bruce and Lampel, Joseph (2008). Strategy Safari: A Guide for Through The Wilds of Strategic Management. New York.

Ohmae, Kinichi (2002), The Borderless World : Power and Strategy in Global Market Place. Profile Books Limited Publisher.

Pemerintah Daerah Kabupaten Belitung Timur (2010), Rencana Pembangunan Jangka Menengah Kabupaten (RPJM) Belitung Timur.

Porter, Michael (1998). Competitive Strategy: Techniques For Analyzing Industries and Competitor. The Free Press.

Rasche, Andreas (2008). The Paradoxial Foundation of Strategic Management. Physica Verlag. Germany.

Setiawan, Indra dan Bratakusumah, Deddy S (2010). Pengaruh Konsumsi, Investasi, Jumlah Uang Beredar dan Inflasi Terhadap Penentuan Kebijakan Suku Bunga SBI. Jurnal Publika Volume 2 Nomor 2, Juli. 2010.

Silvia, Engla Desnim, Wardi Yuniadan Hasdi Aimon (2013), Analisis Pertumbuhan Ekonomi, Investasi dan Inflasi di Indonesia. Jurnal Kajian Ekonomi, Januari 2013, Vol. I. No. 02.

Sjahrial, Darmawan (2007). Manajemen Keuangan Lanjutan. Mitra Wacana Media-Jakarta.

Thomson, Arthur A.; Gamble, John E; Strickland III, A.J. (2010), Stragegy Winning in The Marketplace-Core Concepts, Analytical Tools, Cases. Mc.Graw Hill-Irwin.

UN-Habitat (2005). Promoting Local Economic Development Trough Strategis Planning. Volume 4: Action Guide Series.

Weigh, Tobias (2008). Strategy, Structure, and Performance in Transition Economy. 1st Edition. Gabler Verlag. Germany. 